\title{
Atypical presentation of ocular syphilis in an individual with AIDS
}

\section{Paulo Sérgio Ramos de Araujo[1],[2], Sandra Dias ${ }^{[3]}$ and Fabiana Gonzaga ${ }^{[1]}$}

[1]. Serviço de Doenças Infecciosas e Parasitárias, Departamento de Medicina Tropical, Hospital de Clínicas, Universidade Federal de Pernambuco, Recife, PE. [2]. Laboratório de Doenças Transmissíveis, Centro de Pesquisas Aggeu Magalhães, Fundação Oswaldo Cruz, Recife, PE. [3]. Hospital de Olhos de Pernambuco, Fundação Altino Ventura, Recife, PE.

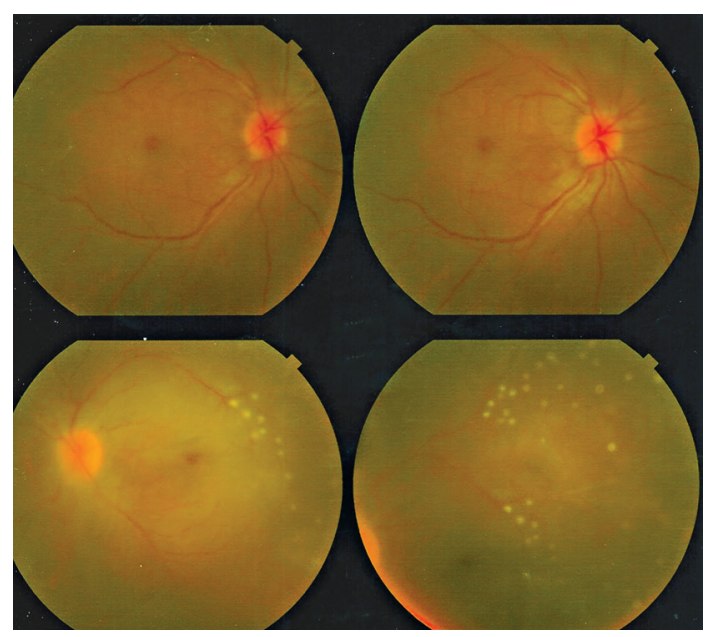

(A)

Ocular complications are common in acquired immunodeficiency syndrome (AIDS) and occur in 50-75\% of patients throughout the course of their illness. Syphilis is the most common bacterial eye infection in these patients and most often presents as uveitis or an optic nerve disease. This condition can manifest as episcleritis, scleritis, dacryoadenitis, anterior uveitis, intermediate uveitis, papillitis, retinal vasculitis, neuroretinitis, or retrobulbar optic neuropathy. The most common symptoms include blurred vision, loss of vision, central scotoma, and bilateral ocular involvement. Although most patients with ocular syphilis do not present with clinical findings, such findings have a high positive predictive value. Patches of creamy, diffuse retinitis with overlying punctate and superficial retinal precipitates have been described as presentations suggestive of ocular syphilis (Figure A). This clinical condition may represent the clinician's first opportunity to diagnose human immunodeficiency virus (HIV) infection and tends to be more severe in individuals who are not yet receiving antiretroviral therapy.

\section{REFERENCES}

1. Hughes EH, Guzowski M, Simunovic MP, Hunyor AP, McCluskey P. Syphilitic retinitis and uveitis in HIV-positive adults. Clin Experiment Ophthalmol 2010; 38:851-856.

2. Balba GP, Kumar PN, James AN, Malani A, Palestine AG, Welch JN, et al. Ocular syphilis in HIV-positive patients receiving highly active antiretroviral therapy. Am J Med 2006; 119:448.e21-25.

3. Kunkel J, Schurmann D, Pleyer U, Ruther K, Kneifel C, Krause L, et al. Ocular syphilis - indicator of previously unknown HIV infection. J Infect 2009; 58:32-36.

Address to: Dr. Paulo Sérgio Ramos de Araujo. Depto de Medicina Tropical/UFPE. Av. Professor Moraes Rego 1125, Cidade Universitária, 52670-901 Recife, PE, Brasil.

Phone/Fax: 5581 2126-3525

e-mail: psergiora@gmail.com

Received 8 January 2014

Accepted 3 February 2014 